\title{
UNSUR-UNSUR SEKULAR DALAM PARTI POLITIK ISLAM DI INDONESIA: KAJIAN TERHADAP PARTAI AMANAT NASIONAL (PAN)
}

\author{
Mohamad Latief \\ Bharudin Che Pa
}

\begin{abstract}
Political secularism is an interesting ideology that deserves thorough academic attention. Set within the context of Indonesian politics where the Muslim community constitutes the majority of the population, this article seeks to critically analyze the secular elements of an Indonesian Islamic political party, namely the Partai Amanat Nasional (PAN). The party is renown, not only because it was established as a result of the processes of Reformasi, but also of its historical and cultural ties with the Muhammadiyah; the second largest Muslim organization in Indonesia. Employing both a political sociology approach and the theory of secularization advanced by Donald Eugene Smith, this qualitative research has identified the secular elements of the PAN. The party's prevailing alignment towards nationalism, at the expense of the fading away of Islam as both political identity and legitimacy of the party, serves to strengthen its secular elements.
\end{abstract}

\section{Pengenalan}

Mengikut hasil satu kajian, transformasi pemikiran politik Islam yang diwawarkan pertama kalinya oleh golongan Islam Kultural ${ }^{1}$ atau Reformis ${ }^{2}$ pada tahun 1970-an, telah menunjukkan kesan yang cukup besar bagi perubahan orientasi ideologi dan pendekatan politik yang diamalkan oleh banyak parti politik Islam di Indonesia, khasnya ketika kekuatan politik Orde Baru runtuh. ${ }^{3}$ Pada tahap tertentu, gerakan pembaruan pemikiran ini mencetuskan aksi-aksi politik yang masih justifiable secara teologi. Namun pada tahap lain, gerakan reaktualisasi pemikiran tersebut menimbulkan kekuatan dekonstruktif terhadap ajaran-ajaran yang sedia ada, dan kemudian menggantikannya dengan fahaman-fahaman baru yang dihasilkan daripada kekuatan kontekstualisasi Islam bagi menyesuaikannya dengan tuntutan zaman.

Ini bererti bahawa Islam mesti disesuaikan dengan perkembangan zaman dan bukan sebaliknya; membentuk perkembangan zaman yang sesuai dengan tuntunan Islam. Fenomena diskursif ini menemukan ruang geraknya di arena politik Indonesia. Realiti tentang masyarakat moden, rasional dan pragmatis, memaksa banyak parti politik Islam untuk melakukan kompromi terhadap keyakinan ideologi mereka. Kompromi ideologipolitik ini biasanya akan dicarikan landasan-landasan teologi, daripada al-Quran dan alSunnah, yang dianggap bersesuaian dan kemudian dikemas kini sedemikian rupa melalui retorik pembenar sehingga tidak nampak hakikatnya yang sebenar.

Oleh itu, ramai masyarakat tidak menyedari berlakunya realiti tersebut. Parti politik pun tidak menyedari bahawa sikap politik mereka telah mencerminkan perilaku-perilaku yang sekular. Yang lebih pelik, terdapat parti politik yang berani melakukan kompromi ideologis demi mencapai matlamat-matlamat mereka, sedangkan mereka sedar bahwa perkara tersebut secara ideologinya tidak dibenarkan. Perkara seumpama ini menunjukkan bahawa parti politik Islam masih mengalami kesulitan bagi menentukan strategi yang tepat untuk menyokong kewujudan mereka dalam sistem politik moden Indonesia yang sekular.

Menerusi kontroversi di atas, amatlah penting untuk diadakan penelitian bagi mengetahui secara kritis unsur-unsur sekularisme dalam parti politik Islam di Indonesia. 
Dalam hal ini, penulis akan menganalisis unsur-unsur tersebut seperti mana yang wujud dalam Partai Amanat Nasional (PAN).

\section{Rasional Pemilihan Partai Amanat Nasional (PAN)}

Terdapat beberapa alasan mengapa penulis memilih Partai Amanat Nasional (PAN) sebagai objek kajian. Antara alasan dimaksud adalah bahawa PAN merupakan parti Islam yang relatif masih muda kerana ditubuhkan pada tahun 1998 dan merupakan representasi parti Islam yang mendapatkan perolehan suara (vote) cukup meyakinkan dan stabil pada setiap pilihan raya semenjak tahun 1999 sehingga 2014. Selain itu, PAN secara tidak langsung ditubuhkan oleh organisasi sosial-politik kemasyarakatan yang terbesar kedua di Indonesia, iaitu Muhammadiyah. Meskipun tidak secara formal menjadi wadah perjuangan politik bagi organisasi kemasyarakatan tersebut, namun PAN memiliki majoriti pengundi daripada organisasi Islam tersebut. Maka, boleh jadi wawasan politik parti tersebut, mengamalkan wawasan politik yang sebenar daripada organisasi yang diwakilinya. Selain itu, sampai pada tahap tertentu, PAN sangat bergantung kepada pemikiran tokoh utamanya iaitu Amien Rais. Dan akhir sekali, PAN merupakan parti politik Islam yang merepresentasikan perjuangan politik Islam langgam baru iaitu politik Islam substantif.

Berkaitan alasan yang terakhir di atas, perlu dijelaskan bahawa semenjak penubuhannya pada tahun 1998, PAN menunjukkan sesuatu bentuk perjuangan politik yang cukup berbeza berbanding bentuk perjuangan politik golongan nasionalis-Islam dan nasionalis-sekular. ${ }^{4}$ Manakala golongan nasionalis-Islam menegaskan perlunya ideologisasi Islam dalam konteks politik nasional, maka kelompok "tengah" ini lebih bersikap moderat dengan menerima Pancasila sebagai ideologi negara. Demikian juga berbanding kelompok kedua. Manakala kelompok nasionalis-sekular menginginkan pemisahan antara agama (Islam) dan negara, kelompok baru ini menegaskan perlunya mengaitkan kedua-dua unsur tersebut. Namun keterkaitan tersebut tidak perlu dilakukan secara simbolistik atau formalistik sepertimana dikembangkan oleh model pendekatan kelompok pertama. Justeru model pendekatan yang diperlukan adalah transformasi nilai-nilai luhur agama (Islam) ke dalam sistem politik dan kenegaraan tanah air dengan menghidarkan diri sejauh mungkin daripada menggunakan simbol-simbol keagamaan yang dinilai terlalu rigid atau kaku.

Inilah paradigma politik substantif sepertimana diperjuangkan oleh PAN. PAN adalah parti politik Islam kerana memiliki basis masa ummat Islam dan dipimpin oleh tokoh-tokoh Muslim. Meskipun demikian, PAN lebih memilih Pancasila, berbanding Islam, sebagai ideologi parti dan menjadikan nasionalisme serta pluralisme sebagai platform politiknya. ${ }^{5}$ Dengan memilih paradigma politik subtantif ini, PAN berusaha memecah kebuntuan pemikiran politik di Indonesia yang terlalu sering dikategorikan secara dikotomis dan berlawanan antara model nasionalis-Islam dan nasionalis-sekular sepertimana disebutkan di atas. Dengan bersikap moderat dan bergerak ke tengah tanpa menyebelahi mana-mana pihak tersebut secara ekstrim, PAN berupaya meletakkan sesuatu bentuk hubungan yang harmoni antara agama (Islam) dan negara. Hal ini dilakukan dengan sedikit sebanyak menampung unsur-unsur politik Islam dan sekular secara bersamaan dalam satu gengaman tangan.

\section{Unsur-Unsur Sekular dalam PAN}

Menurut Donald Eugene Smith, aspek-aspek sekularisme dan khasnya sekularisasi politik secara amnya dapat dikategorikan ke dalam empat aspek; iaitu sekularisasi sebagai keterpisahan negara (polity-separation secularization), sekularisasi sebagai pengembangan negara (polity-expansion secularization), sekularisasi sebagai penilaian ulang terhadap nilainilai lama (polity-transvaluation secularization) dan sekularisasi sebagai dominasi negara (polity-dominance secularization). ${ }^{6}$ 


\section{Polity-Separation Secularization}

Unsur sekularisme politik pada tahap ini, biasanya dilekatkan dengan kondisi sosial keagamaan sesebuah negara yang sangat beragam. Dalam sebuah negara yang majmuk, perdebatan mengenai perkara-perkara asas yang berkait persatuan dan kesatuan akan selalu muncul di setiap waktu dan kesempatan. Membangun sebuah sistem kehidupan yang kuat di tengah-tengah masyarakat yang pelbagai merupakan persoalan serius yang tidak pernah lekang oleh perubahan zaman dan waktu. Kewujudan golongan minoriti selalu saja mengundang perhatian pemerintah terlebih lagi dalam kaitannya dengan golongan majoriti yang secara sosial keagamaan adalah masyarakat terbesar. Tidak jarang, percikan-percikan pertelingkahan muncul dan terus saja berkembang sedemikian rupa sebagai akibat daripada hubungan yang kurang harmoni antara kedua-dua kelompok masyarakat tersebut. Rendahnya kesedaran terhadap sikap hormat menghormati dan lemahnya sikap toleransi, sering kali dituduh sebagai punca pertelingkahan semacam ini.

Salah satu prinsip politik yang perlu diperjuangkan oleh negara untuk menegakkan persatuan dan kesatuan bangsa adalah prinsip persamaan (equality). Demikian pula halnya dengan PAN. Parti politik ini berusaha memperjuangkan nilai persamaan tersebut. Hal ini diwujudkan dengan menjadi parti nasionalis dan terbuka. Meskipun memiliki kaitan sejarah dengan salah satu organisasi massa Islam terbesar di Indonesia, namun perkara tersebut tidak menghalangi PAN untuk menentukan jalan politiknya menjadi parti inklusif. Perlu diingat bahawa dalam sejarah politik tanah air, Islam dan nasionalisme pernah memiliki hubungan yang kurang harmoni. ${ }^{7}$ PAN ingin meletakkan Islam dan nasionalisme dalam sebuah hubungan yang harmoni apabila kecintaan terhadap negara mestilah dibentuk secara selaras dengan kecintaan terhadap Islam. Dengan pilihan politik seumpama ini, PAN tidak lagi terjebak dalam dikotomi kelompok Islam atau kelompok nasionalis dan tidak mengalami kesusahan untuk menunjukkan khidmatnya secara terus bagi kemaslahatan seluruh bangsa Indonesia.

Apabila kita merujuk kepada Anggaran Dasar dan Rumah Tangga parti, komitmen PAN terhadap nilai persamaan amatlah jelas iaitu, "Partai Amanat Nasional adalah partai yang terbuka bagi warga negara Indonesia, laki-laki dan perempuan yang berasal dari berbagai pemikiran, latar belakang etnis maupun agama, dan mandiri". ${ }^{8}$

Melalui kenyataan seumpama ini, amatlah jelas bahawa PAN ditubuhkan di atas nilai persamaan. Komitmen terhadap nilai persamaan tersebut direalisasikan dengan menjadi parti politik yang demokratis dan terbuka. Seluruh warga Indonesia dipandang sejajar dan memiliki hak yang sama untuk menyalurkan aspirasi politik mereka melalui PAN. Parti politik ini tidak menutup dirinya secara eksklusif dengan menerima keanggotaan hanya dalam golongan tertentu sahaja. Namun parti politik tersebut membuka diri dan menerima keanggotaan dari seluruh bangsa Indonesia tanpa mengira latar belakang agama, etnis dan budaya mereka. PAN berjaya untuk tidak menyebelahi mana-mana pihak tertentu secara melampau atau bersikap eksklusif namun justeru dapat menyejajarkan hak politik seluruh bangsa Indonesia dalam satu taraf atau tingkatan yang sama. Pensejajaran taraf, kesaksamaan dan berkecuali (neutrality) menjadi isu terpenting berkait nilai persamaan sepertimana diamalkan oleh PAN.

Dalam hal ini, wujud perkara lain yang tidak kalah menarik untuk diperbincangkan, iaitu mengenai posisi Islam dalam platform parti. Nampaknya PAN betul-betul konsisten dengan komitmennya terhadap nilai persamaan. Parti politik ini bersikap neutral dan tidak menunjukkan pemihakan yang melampau terhadap Islam. Paling tidak, kenyataan ini dapat dianalisis melalui pembacaan terhadap Anggaran Dasar dan Rumah Tangga parti yang tidak menyebutkan Islam atau agama-agama tertentu lainnya, secara eksplisit. Platform mahupun piagam penubuhan parti tidak menyatakan secara jelas di mana kedudukan Islam 
dalam tubuh PAN. Meskipun ditemui beberapa kenyataan yang secara implisit berkait rapat dengan Islam, ia tidak bererti keberpihakan parti secara eksklusif terhadap Islam. Berkait kenyatan-kenyataan dimaksud, Anggaran Dasar dan Rumah Tangga parti tidak menyebutkan secara eksplisit posisi Islam dalam tubuh dan platform PAN. Berkaitan asas dan visi parti misalnya, disebutkan bahawa:

Asas Partai Amanat Nasional adalah akhlak politik berlandaskan agama yang membawa rahmat bagi sekalian alam. ${ }^{9}$

Terwujudnya PAN sebagai partai politik terdepan dalam mewujudkan masyarakat madani yang adil dan makmur, pemerintah yang baik dan bersih di dalam Negara Indonesia yang demokratis dan berdaulat serta di ridhai Allah Subhanahu wata'ala, Tuhan Yang Maha Esa. ${ }^{10}$

Menurut perspektif Islam, Ketuhanan Yang Maha Esa bererti tauhid (monotheism) yang memiliki peranan penting untuk menjiwai sila-sila berikutnya dalam Pancasila. Ia merupakan suatu konsep ketuhanan yang mengakui Allah SWT sebagai satu-satunya Tuhan yang wajib dipercayai dan disembah. Sila pertama Pancasila ini juga merujuk kepada sebuah konsep keimanan Islami yang berpaksikan pada keyakinan bahawa tiada Tuhan selain Allah SWT dan bahawa Muhammad adalah utusan Allah SWT. ${ }^{11}$ Bagi setiap Muslim, konsep ketuhanan seumpama ini adalah benar dan perlu dijadikan sebagai landasan utama untuk berfikir, bersikap dan bertindak. Jadi setiap gerak langkah, tingkah laku dan pola fikir seorang Muslim, mestilah dibentuk secara beriringan mengikut konsep ketuhanan tersebut.

Demikian pula menurut pandangan PAN. Setiap ahli PAN yang beragama Islam meyakini bahawa Ketuhanan Yang Maha Esa merupakan inti ajaran tauhid. Sila pertama tersebut secara jelas merefleksikan spirit keislaman apabila perkataan 'Esa' merupakan antara sifat ketuhanan yang hanya dimiliki oleh Allah SWT. Seorang tokoh PAN, Achmad Rubaie misalnya menyatakan bahawa Islam adalah agama yang kaya dengan simbol-simbol dan makna. Apabila keduanya diperhadapkan, maka makna atau esensi menjadi lebih penting berbanding simbol-simbol tersebut. Menurutnya, Ketuhanan Yang Maha Esa merupakan symbol dan Tauhid adalah makna daripada simbolisasi tersebut. Sila pertama ini sejajar dengan penyebutan-penyebutan yang baik lainnya terhadap Allah seperti alRahman, al-Rahim, al-Wahid dan sebagainya. ${ }^{12}$

Meskipun demikian, pemaknaan seumpama ini bukanlah pandangan rasmi PAN. Parti politik ini tidak mengertikan Pancasila dalam pemaknaannya yang berimplikasi tauhid. Namun PAN memahami Pancasila sebagai sebuah sistem nilai yang terbuka dan oleh itu tidak boleh dimaknai secara sepihak oleh satu bentuk pemaknaan saja. Pancasila mestilah didekati dan ditafsirkan melalui pelbagai bentuk dan jalan pendekatan. Dengan itu, seluruh sila-sila Pancasila dan khasnya sila Ketuhanan Yang Maha Esa, tidak boleh difahami dari perspektif Islam sahaja. Ia perlu difahami secara terbuka melalui pemaknaan lain menurut perspektif agama Kristian, Katholik, Hindu dan sebagainya. Setiap ahli PAN atau bahkan seluruh warga Indonesia berhak untuk memberikan pemaknaan mereka terhadap sila Ketuhanan Yang Maha Esa tersebut mengikut agama dan kepercayaan masing-masing. ${ }^{13}$ Parti tidak berhak untuk menentukan pemaknaan tersebut secara eksklusif kerana ia menunjukkan pemihakan terhadap salah satu kelompok atau golongan tertentu sahaja. Pemihakan seumpama ini adalah bentuk pelanggaran terhadap prinsip-prinsip demokrasi yang dibangunkan khasnya persamaan.

Dengan mengambil kira fahaman seumpama ini, maka sila Ketuhanan Yang Maha Esa memiliki makna yang beragam. Ianya tidak serta merta bermakna Tauhid, sepertimana diyakini oleh golongan Muslim, namun dapat juga diertikan sebagai Ketuhanan dalam konteks pemaknaannya yang lebih luas. Dalam konteks seumpama ini, Ketuhanan dapat 
berarti kepercayaan terhadap konsep Triniti sepertimana diyakini golongan Kristiani, Budhisme menurut penganut agama Buddha atau juga Hinduisme menurut pemeluk agama Hindu dan sebagainya. Setiap warga negara berhak untuk memberikan pentafsirannya terhadap sila Ketuhanan Yang Maha Esa, dan seluruh sila-sila Pancasila lainnya, mengikut keyakinan dan agama yang dipeluknya. Semua bentuk pentafsiran tersebut adalah benar dan oleh itu diletakkan secara sejajar dalam platform parti. Namun perlu diingat, bahawa setiap bentuk pentafsiran yang sangat beragam di atas adalah bersifat peribadi dan personal serta tidak boleh dipaksakan untuk menjadi satu-satunya pemaknaan parti. Oleh itu, bentuk pentafsiran yang dikehendaki semestinya bersifat am, menyeluruh dan inklusif sehingga dapat merangkumi pemaknaan eksklusif yang diberikan oleh setiap agama dan kepercayaan yang diyakini oleh tiap-tiap warga PAN.14

Demikianlah posisi Islam dalam landasan politik PAN. Islam menempati posisi yang amat penting dalam landasan politik parti politik tersebut. Namun demikian, ia tidak diletakkan sebagai acuan tertinggi bagi menentukan sikap dan pemikiran politik parti. Islam diletakkan sejajar dengan agama-agama atau kepercayaan lainnya yang dianuti oleh warga parti. Ia hanya menjadi antara faktor komplementer atau pelengkap yang memberikan sistem nilai dan pedoman politik bagi PAN. Para pendiri parti politik tersebut sedar bahawa kepelbagaian secara sosial, budaya, agama politik masyarakat Indonesia, merupakan suatu berkah dan oleh itu perlu diperkasakan dan diikat dalam sebuah hubungan kebangsaan yang inklusif. Ikatan tersebut tidak bersifat ideologis-teologis. Ia tidak berasal dari satu agama (Islam) namun dari kesatuan agama-agama. PAN meyakini bahawa setiap agama adalah unik dan dalam keunikan tersebut, wujud kesatuan nilai sejagat atau ajaran yang menyatukan agama-agama tersebut. Antara nilai-nilai tersebut adalah perdamaian, kejujuran, musyawarah, bertanggung jawab dan sebagainya.

Pilihan untuk mengambil sikap politik seumpama ini sememangnya tidak dapat dilepaskan daripada komitmen parti untuk memperjuangkan prinsip persamaan. Sepertimana dijelaskan di atas, PAN adalah parti moden dan demokratis yang memperjuangkan prinsip persamaan. Kebijakan politik ini ditunjukkan dengan menjadi parti inklusif atau membuka diri secara sruktural mahupun keanggotaan bagi seluruh rakyat Indonesia tanpa mempermasalahkan latar belakang agama, budaya dan sosial mereka. Lebih dari itu, prinsip persamaan juga mendorong parti untuk terbuka secara ideologis. Pilihan PAN untuk menjadikan Pancasila sebagai ideologi parti sememangnnya dilatarbelakangi oleh konteks agama, sosial, politik bangsa Indonesia yang beragam. Bagi PAN, ideologi politik tidak dapat diperolehi melalui pemikiran yang mendalam terhadap ajaran-ajaran satu agama (Islam) sahaja. Ideologi politik semestinya dibentuk melalui upayaupaya pemaknaan yang menyeluruh terhadap setiap agama dan kemudian penyelarasannya dengan konteks kenegaraan Indonesia sebagai bangsa yang pelbagai.

Jelas, komitmen untuk mengamalkan prinsip persamaan ini telah menimbulkan fahaman sekularisme dalam tubuh PAN. Sekularisme politik pada tahap ini mewujud dalam ketidakberpihakan PAN secara eksklusif terhadap Islam atau mana-mana agama lainnya. Justeru parti politik ini menjadikan nilai-nilai sejagat, yang diajarkan oleh tiap-tiap agama sebagai landasan dan cita-cita politiknya. Nilai-nilai sejagat tersebut dianggap sebagai semacam "kalimatun sawa" atau titik temu yang menyatukan seluruh agama di Indonesia dalam satu ajaran universal yang sama. Dalam konteks ini, Pancasila dapat dianggap sebagai perwujudan kalimatun sawa tersebut. Jadi secara ringkas, ketidakberpihakan PAN secara eksklusif terhadap Islam ini berlaku dalam beberapa perkara. Antaranya ketiadaan penyebutan Islam secara jelas dalam Anggaran Dasar dan Rumah Tangga parti, tidak terdapat penyebutan satu agama tertentu (Islam) sebagai agama yang diistimewakan dan keengganan PAN untuk disebut sebagai parti Islam. ${ }^{15}$

\section{Polity-Expansion Secularization}


Dalam kategori kedua ini, parti mula memperluas wilayah kekuasaannya untuk mentadbir bidang-bidang sosial dan ekonomi yang dulu berada di bawah dan ditadbir oleh kuasa agama atau golongan agamawan. Upaya perluasan wilayah cakupan parti yang sedemikian, sememangnya didasarkan pada keinginan untuk menubuhkan kuasa yang besar lagi menyeluruh dan juga keinginan untuk melakukan perubahan-perubahan sosial, politik dan ekonomi dalam sesebuah masyarakat moden. Proses sekularisasi ini berlaku ke atas beberapa bidang iaitu; sekularisasi hukum, pendidikan, struktur sosial dan ekonomi. Dalam kajian ini, perbahasan akan berkisar pada struktur sosial sahaja. ${ }^{16}$

Dalam kehidupan sosial masyarakat tradisional, khasnya masyarakat Kristian Katholik, Islam dan Hindu, wujud doktrin keagamaan yang meletakkan masyarakat ke dalam golongan atau hierarki tertentu. Tingkatan sosial kemasyarakatan seumpama ini dianggap perkara yang wajar dan telahpun mendapat pembenaran daripada pihak pemerintah atau kerajaan. Keadaan sosial kemasyarakatan sebegini biasanya berlaku pada masyarakat yang meyakini satu ideologi keagamaan yang sama. Namun begitu, keadaan seumpama ini tidak dapat bertahan lama. Kemunculan generasi baru, sama ada berasal daripada dalam mahupun luar masyarakat tradisional dimaksud, dan memiliki paradigma pemikiran berbeza, berusaha melakukan penentangan terhadap kewujudan tingkatan sosial tersebut. Bagi generasi baru ini, sistem masyarakat moden mestilah ditubuhkan di atas prinsip persamaan ke atas seluruh rakyat dan diatur secara ketat oleh negara. ${ }^{17}$

Secara amnya dapat dikatakan bahawa sekularisme pada tahap ini merupakan kelanjutan daripada sekularisme pada tahap pertama iaitu polity-separation secularization. Perbahasan kali ini masih berkait rapat dengan masalah atau prinsip persamaan (equality). Kemudian dalam konteks PAN, perkara ini wujud dalam bentuk keterbukaan parti untuk menerima keanggotaan daripada seluruh bangsa Indonesia tanpa mengira latar belakang agama, pendidikan, jenis kelamin dan ideologi mereka. Sepertimana penulis jelaskan sebelum ini, bahawa komitmen PAN untuk menghormati kepelbagaian di Indonesia, telahpun mendorong parti politik tersebut untuk memperjuangkan prinsip-prinsip demokrasi khasnya persamaan. Komitmen terhadap demokrasi ini kemudian menuntut PAN untuk menjadi parti yang terbuka, inklusif dan tidak sektarian. Tidak hanya terbuka secara struktural keanggotaan, ternyata PAN juga terbuka secara ideologis mahupun kefahaman politik. Dengan menjadi parti pengusung demokrasi, PAN menunjukkan paradigma politik yang cukup berbeza dengan parti-parti Islam lainnya yang muncul sebelum era reformasi. Komitmen PAN untuk memperjuangkan prinsip persamaan dan menjadi parti yang inklusif atau terbuka, bercanggah dengan paradigma politik langgam lama yang diwakili oleh misalnya Masyumi. Dalam Anggaran Dasar dan Rumah Tangga Masyumi tentang keanggotaan disebutkan bahawa anggota parti terdiri daripada anggota biasa, teras dan istimewa. Anggota biasa adalah warga negara Indonesia yang beragama Islam (laki-laki dan perempuan) dan tidak menjadi anggota parti politik lain. Anggota teras, terpilih daripada anggota-anggota biasa dan anggota istimewa ialah pengurus besar/ pusat perhimpunan Islam yang bukan parti politik. Selain itu juga disebutkan bahawa setiap anggota mestilah beragama Islam. Masyumi dengan tegas melarang keanggotaan daripada golongan bukan Muslim apatah lagi menjadi pengurus parti. ${ }^{18}$

Jelas sekali bahawa paradigma politik seumpama ini tidak dianuti oleh PAN. Parti politik ini memiliki cara pandang yang cukup berbeza berbanding fahaman politik Masyumi. PAN tidak melarang sesiapa sahaja warga negara Indonesia untuk menjadi anggotanya meskipun wujud perbezaan latar belakang agama, budaya, jenis kelamin dan pendidikan di antara mereka. PAN juga tidak berkeberatan untuk menunjuk beberapa orang tertentu daripada golongan bukan Islam untuk menjadi pengurus parti. Terdapat sejumlah nama bukan Muslim dalam kepengurusan parti antaranya Sindhunata, TH Sumartana, Albert Hasibuan, ${ }^{19}$ Laurens Bahang Dama, Alvin Lie, Bara Hasibuan, Yosef Pagar Fernando, Jerremy Thomas, ${ }^{20}$ Christianto Wibisono, Nyoman Gde Suweta, Ida Bagus 
Wirahadi dan sebagainya. ${ }^{21}$ Dalam setiap pilihan raya, parti ini selalu mengajukan beberapa nama bukan Islam untuk menjadi calon anggota dewan sama ada di tingkat daerah (propinsi) mahupun tingkat pusat (nasional). Boleh jadi dalam pilihan raya 2014, bilangan calon anggota legislatif dimaksud adalah lebih ramai berbanding dengan pilihan rayapilihan raya sebelumnya. Yang pasti pada pilihan raya kali ini, PAN telah mempersiapkan calon-calon anggota legislatif yang pelbagai namun berkualitas. Bara Hasibuan menyatakan;

Soal Daftar Calon Legislatif Sementara ini juga menunjukkan komitmen PAN sebagai partai terbuka, contohnya di daerah yang berbasis umat kristiani, mayoritas calegnya dari tokoh-tokoh Kristen. ${ }^{22}$

PAN yang menginginkan Indonesia baru, modern, dan plural. Indonesia Timur caleg didominasi caleg beragama Kristen. Di Sumatra Utara juga demikian.... Di Bali, kali inilah pertama kalinya sejak berdiri 1998, caleg PAN didominasi orang Bali. Di Kalimantan Tengah, kita punya caleg beragama Buddha. ${ }^{23}$

Demikianlah karakter terbuka sepertimana diamalkan oleh PAN. Selain keterbukaan secara keanggotaan, ternyata parti politik tersebut membuka diri secara struktural terhadap golongan bukan Islam. Ini terbukti melalui ramainya bilangan bukan Islam dalam kepengurusan parti dan calon anggota legislatif sama ada di peringkat daerah atau nasional.

Dalam konteks ini, apabila kita merujuk kepada khazanah keilmuan politik Islam Siyasah Syariah sendiri, terdapat perbahasan yang cukup menarik berkait kepemimpinan bukan Islam dalam masyarakat Muslim. Pertanyaan yang biasa diajukan antaranya adalah sejauh mana hak-hak politik golongan bukan Islam dalam struktur negara Islam dan bagaimana cara mengatur pelaksanaan hak-hak politik tersebut secara bersesuaian dengan al-Quran dan al-Sunnah. Pertanyaan seumpama ini biasanya menyempit lagi menjadi "dapatkah seseorang daripada golongan bukan Islam menjadi kepala negara atau ahli parlimen" dan sebagainya. Berkait perkara ini, para fuqaha bersetuju bahawa golongan bukan Islam sememangnya memiliki hak-hak politik yang sama dengan golongan Islam (Muslimin). Tidak semestinya mereka mendapatkan perlakuan diskriminatif atau dilarang dari mendapatkan hak-hak politik mereka untuk berjuang dan berbakti kepada negara.

Meskipun demikian, para fuqaha secara amnya bersepakat bahawa persamaan hak politik tersebut tidak berlaku ke atas beberapa perkara tertentu. Terdapat beberapa wilayah politik apabila golongan bukan Islam tidak diberikan kebenaran untuk mendapatkannya. Sebaliknya, wilayah-wilayah politik tersebut mestilah diberikan secara eksklusif kepada ummat Islam sahaja. Antara perkara-perkara tersebut adalah kekuasaan militer, ${ }^{24}$ bidang kuasa perundang-undangan keislaman, ${ }^{25}$ perkahwinan, ${ }^{26}$ kekuasaan atau otoriti pemerintahan dan sebagainya. Berkait perkara yang disebut terakhir ini, para fuqaha meyakini bahawa otoriti pemerintahan mestilah ditadbir dan dilakukan sepenuhnya oleh kaum Muslimin. Seluruh bidang kerja atau jawatan politik yang berkait dengan pengambilan keputusan negara, adalah hak penuh kaum Muslimin apabila golongan bukan Islam tidak diperkenankan untuk ikut campur di dalamnya. ${ }^{27}$

Kenyataan seumpama ini biasanya disandarkan pada surah al-Nisa, ayat 59 yang bermaksud:

Wahai orang-orang yang beriman, taatlah kamu kepada Allah dan taatlah kamu kepada Rasulullah dan kepada "Ulil-Amri" (orang-orang yang berkuasa) dari kalangan kamu. Kemudian jika kamu berbantah-bantah (berselisihan) dalam sesuatu perkara, maka hendaklah kamu mengembalikannya kepada (Kitab) Allah (Al-Quran) dan (Sunnah) Rasul- 
Nya; jika kamu benar beriman kepada Allah dan hari akhirat. Yang demikian adalah lebih baik (bagi kamu), dan lebih elok pula kesudahannya. ${ }^{28}$

Perdebatan lain yang tidak kurang menariknya adalah mengenai boleh atau tidaknya seseorang bukan Islam untuk menjadi anggota Majlis al-Shura. Ketika memperbincangkan permasalahan ini, para fuqaha secara amnya terbahagi menjadi dua bahagian; bahagian yang tidak memperbolehkan dan bahagian yang memperbolehkan golongan bukan Islam untuk menjadi anggota Majlis al-Shura. Pendapat yang tidak memperbolehkan diwakili oleh misalnya Sayyid Qutb, Abu al'A'la al-Mawdudi, Sa'id Hawa dan sebagainya. ${ }^{29}$ Mereka memahami bahawa negara mestilah ditadbir secara Islami atau berdasarkan pada nilai-nilai Islam. Pentadbiran seumpama ini tidak dapat dapat dilakukan melainkan oleh orang-orang yang mengimani dan memahami nilai-nilai Islam tersebut. Oleh itu, kepala negara dan Majlis al-Shura mestilah dijabat dan ditadbir secara eksklusif oleh orang Islam.

Berbeza dengan pendapat pertama ini, para fuqaha yang memperbolehkan seseorang bukan Islam untuk menjadi bahagian dalam Majlis al-Shura berkeyakinan bahawa khazanah kesejarahan keislaman mencatit beberapa kejadian sejarah apabila Rasulullah SAW meminta nasihat kepada bukan Islam di atas perkara tertentu. ${ }^{30} \mathrm{Hal}$ ini menunjukkan bahawa untuk perkara-perkara tertentu, diluar pengambilan keputusan, dan ummat Islam tidak diberikan pengetahuan ke atasnya, mereka diberikan kebenaran untuk memintakan nasihat atau pertimbangan daripada golongan bukan Islam. Oleh itu, sebahagian fuqaha membolehkan golongan bukan Islam untuk memegang jawatan di Majlis al-Shura. Meskipun demikian, para fuqaha cukup berhati-hati untuk menyatakan pendapat seumpama ini.

Terdapat beberapa prasyarat apabila golongan bukan Islam diperbolehkan untuk masuk dan berkhidmat di dalam Majlis al-Shura. Antara prasyarat tersebut adalah bahawa golongan bukan Islam hanya diberikan kebebasan untuk memberikan pertimbangan atau perundingan berkait permasalahan-permasalahan yang am atau permasalahanpermasalahan yang berkait rapat dengan golongannya sahaja. ${ }^{31}$ Selain itu, undang-undang atau hukum yang dikeluarkan oleh Majlis al-Shura mestilah bersesuaian dengan nilai-nilai al-Quran dan al-Sunnah. Maka dengan itu dapat difahami bahawa nasihat ataupun pertimbangan yang diberikan oleh seorang bukan Islam dalam Majlis al-Shura mestilah diambilkira dan dinilai melalui kacamata Islam. Prasayarat berikutnya menegaskan bahawa al-Quran dan al-Sunnah mestilah dijadikan sebagai sumber hukum tertinggi. Setiap perundangan mestilah bermuara pada ajaran al-Quran dan al-Sunnah serta tidak bercanggahan dengan keduanya. Perlu ditegaskan juga bahawa perundangan tersebut perlu dikuatkuasakan dan diamalkan oleh seorang penguasa yang beragama Islam. ${ }^{32}$

Kembali kepada masalah keterbukaan PAN. Terdapat perbahasan lain yang juga menarik untuk diperbincangkan, iaitu berkait kepemimpinan perempuan. Selain membuka kemungkinan bagi golongan bukan Islam untuk menjadi ketua umum parti, PAN mendukung kepemimpinan perempuan. PAN pernah mendukung Megawati Soekarno Putri sebagai Presiden ke-5 Indonesia. Meskipun sebelumnya tidak mendukung Megawati sebagai calon presiden Republik Indonesia ke-4, namun PAN berubah haluan menyatakan sokongannya terhadap beliau ketika Gus Dur diturunkan daripada kursi presiden pada 23 Julai 2001. Sokongan PAN terhadap Megawati ditegaskan oleh Amien Rais sebagai Ketua Umum PAN pada ketika itu dalam sebuah Rapat Kerja Nasional di Denpasar, Bali. Keputusan untuk menyokong Megawati menjadi presiden tersebut, disahkan oleh peserta mesyuarat sebagai rekomendasi politik rasmi PAN. Menurut Amien Rais:

Yakni, jika Presiden (Gus Dur) mundur, berhalangan tetap atau dimundurkan lewat Sidang Istimewa oleh MPR, maka secara otomatis, 
Wapres (Mega) akan naik menjadi presiden, dan itu sesuai konstitusi. Tentu kita tidak akan memberikan cek kosong kepada Mega. Insya Allah Mega akan kita dukung lewat aturan main, lewat fatsoen politik dan etika demokrasi. Pokoknya yes, kita dukung Mega. ${ }^{33}$

Menurut perspektif Siyasah Syariyyah, Islam tidak menganjurkan kepemimpinan perempuan atau bahkan melarangnya sama sekali. Para fuqaha telahpun memperbincangkan permasalahan seumpama ini. Selain perbahasan mengenai hak politik bukan Islam, perbincangan mengenai hak politik kaum perempuan juga telah menyita perhatian para fuqaha terdahulu. Antara pokok permasalahan yang sering diperbincangkan adalah "bolehkah seorang wanita menjadi kepala negara?" Secara amnya dapat diperkatakan bahawa seorang wanita memiliki hak politik yang sama berbanding seorang lelaki. Menurut para fuqaha, Islam memperbolehkan kaum wanita untuk bekerja atau mengetuai bidang-bidang atau jawatan-jawatan umum semacam hakim, gabenor, petugas jawatan hisbah, petugas jawatan rungutan (waliy al-Mazalim) dan sebagainya. Kesemua bidang dan jawatan di atas tidak hanya menjadi wilayah kerja yang dikuasai oleh kaum pria, namun kaum wanita juga diberikan kebenaran untuk bersaing bagi memperebutkan dan berkhidmat di dalamnya. Meskipun demikian, para fuqaha juga bersepakat bahawa Islam tidak memberikan kebenaran bagi kaum perempuan untuk memangku jawatan kepala negara (wazir al-tafwidz) seperti presiden atau perdana menteri. ${ }^{34}$

Maka dengan mengambil kira paradigma politik keislaman di atas, dapat disimpulkan bahawa langkah politik PAN untuk mengangkat golongan bukan Islam dalam kepengurusan parti adalah bercanggahan dengan fahaman para fuqaha. Dukungan PAN terhadap Megawati, betapapun pragmatis alasannya, menunjukkan bahawa parti tersebut tidak menjadikan Islam sebagai pijakan utama untuk membentuk cara pandang dan perilaku politiknya. Hal ini kerana kepemimpinan wanita, iaitu sebagai kepala negara, tidak dibenarkan oleh Islam melainkan wujudnya perkara-perkara tertentu yang membolehkan perkara seumpama ini berlaku ke atas sebuah negara. ${ }^{35}$

\section{Polity-Transvaluation Secularization}

Sekularisme pada tahap ini, berkait rapat dengan sekularime pada budaya politik. Apabila ianya kita fahami sebagai natijah dari sebuah proses, maka sesungguhnya sekularisme dalam budaya politik ini memiliki persoalan yang jauh lebih kompleks berbanding polityseparation dan polity-expansion. Manakala kedua tahap di atas dapat berlaku dalam masa yang tidak terlalu lama, kerana ianya dapat dilakukan secara paksa oleh para elit parti tanpa mengambil kira persetujuan rakyat. Sekularisme pada tahap ketiga ini berlaku dalam sebuah proses panjang yang memakan waktu cukup lama. Ini kerana sekularisme dalam budaya politik melibatkan perubahan mendasar dalam struktur nilai dalaman apabila para elit penguasa tidak dapat mengarahkannya secara efektif dalam waktu yang singkat. ${ }^{36}$

Di sebalik sekularisasi budaya politik ini, wujud fakta yang menunjukkan bahawa nilai-nilai keagamaan (keislaman) secara amnya mulai memudar. Keberagamaan (religiosity) dan ketaatan (piety) seseorang Muslim terhadap Islam tidak lagi dipandang sebagai nilai lebih di mata masyarakat. Sebaliknya, masyarakat mula beralih mengejar nilai-nilai materialisme kerana ianya dianggap memiliki tingkatan yang lebih tinggi di atas nilai-nilai agamis. Pola hubungan sosial kemasyarakatan yang dulu diatur secara ketat menurut ajaran agama tertentu (Islam), juga mengalami perubahan yang berarti. Kini masyarakat moden mendapati bahawa nilai-nilai agama (Islam) yang cenderung eksklusif dilihat tidak cukup memadai untuk menjamin terciptanya pola hubungan sosial kemasyarakatan yang demokratis, terbuka dan dapat diterima oleh semua pihak. Sebagai gantinya, masyarakat mula beralih untuk mencari sistem nilai baharu yang lebih inklusif dan toleran apabila nilai- 
nilai sejagat, semacam kebaikan, perdamaian, persamaan, persaudaraan dan sebagainya, dapat difahami secara bebas dan terbuka. ${ }^{37}$ Untuk mengetahui sekularisme pada tahap ini, perlu diketengahkan dua aspek utama dalam budaya politik parti. Keduanya adalah berkait dengan basis legitimasi dan identiti kelompok.

\section{Sekularisme Pada Asas Legitimasi}

Dalam struktur masyarakat tradisional, legitimasi politik yang dimiliki pemerintah sememangnya bersifat agamis (divine) atau bersumber daripada agama (Islam). Karakter dan tugasan yang diamalkan oleh pemerintah ditentukan dan diatur oleh agama tersebut. Namun, keadaan seumpama ini berubah ketika sistem masyarakat moden mula muncul dan berkembang secara meluas. Tidak hanya berlaku dalam sistem sosial kemasyarakatan sahaja, namun perubahan tersebut juga terjadi dalam hal legitimasi politik. Dalam masyarakat moden, legitimasi politik tidak lagi didapatkan daripada agama (Islam), namun diberikan oleh ideologi politik alternatif semacam demokrasi, nasionalisme, komunisme, kapitalisme dan sebagainya. Yang pasti, satu-satunya fakta yang menandai keruntuhan struktur masyarakat tradisional adalah sistem pemerintahan yang tidak lagi mendasarkan klaim legitimasinya ke atas nilai ilahiyah (divine). 38

Dalam konteks PAN, sekularisme pada basis legitimasi ini dapat dianalisis melalui beberapa perkara. Antaranya penerimaan PAN terhadap demokrasi dan nasionalisme. PAN amat mendukung tegaknya demokrasi di Indonesia dan memiliki komitmen tinggi untuk memperjuangkan nilai-nilai demokrasi. Paling tidak kenyataan seumpama ini, dapat dilihat daripada AD \& ART parti. Di dalamnya disebutkan bahawa PAN bercita-cita mewujudkan masyarakat madani yang adil dan makmur, pemerintahan yang baik dan bersih di dalam negara Indonesia yang demokratis dan berdaulat serta diredhai oleh Allah SWT Tuhan Yang Maha Esa. Dalam misi parti, juga dinyatakan bahawa PAN menegaskan cita-citanya untuk mewujudkan Indonesia baru yang demokratis, makmur, maju, mandiri dan bermartabat. ${ }^{39}$ Platform parti juga menyatakan bahawa PAN merupakan parti politik yang memperjuangkan kedaulatan rakyat, demokrasi, kemajuan dan keadilan sosial apabila setiap warganegara dapat mengembangkan dirinya sehingga mampu berperanan dalam kehidupan politik, sosial, ekonomi dan sebagainya.40

Menurut pengamatan penulis, penerimaan terhadap demokrasi ini menunjukkan wujudnya sekularisme pada basis legitimasi politik dalam tubuh PAN. Kenyataan ini dapat dijelaskan seperti berikut. Dengan menjadikan demokrasi sebagai matlamat politiknya, PAN meyakini bahawa kedaulatan sepenuhnya berada di tangan rakyat. Ini tentu bercanggahan dengan dalil-dalil Islam yang menyatakan bahawa kedaulatan berada di tangan Allah SWT semata. ${ }^{41}$ Memang sehingga setakat ini wujud pendapat yang menyatakan bahawa kedaulatan rakyat tidak perlu dipertentangkan dengan kedaulatan Tuhan. Ini kerana kedaulatan Tuhan sememangnya dapat diwakilkan kepada kedaulatan rakyat. Dengan menjadikan makna khalifah tidak terpaku pada seseorang penguasa sahaja, dan melekatkannya pada setiap manusia, maka dapat disimpulkan bahawa kehendak Tuhan dapat menjelma dalam kehendak rakyat yang disalurkan dalam pemerintahan perwakilan. ${ }^{42}$

Namun yang menjadi masalah adalah bahawa anggota PAN tidak semestinya beragama Islam. Ada diantara mereka yang beragama Kristen, Katolik, Hindu, Buddha dan sebagainya. Tentu akan menjadi rancu apabila perkataan khalifah di atas digunakan untuk merujuk kepada seluruh anggota tersebut. Padahal jelas bahawa yang dimaksud dengan khalifah sepertimana disebutkan dalam al-Quran adalah setiap manusia yang meyakini tawhid dan mengimani bahawa Muhammad SAW adalah utusan-Nya.43 Dengan pemahaman seumpama ini, dapat disimpulkan bahawa kedaulatan rakyat sepertimana difahami oleh PAN menunjukkan kedaulatan rakyat yang pelbagai dan beragam atau juga ianya bererti kedaulatan seluruh penganut agama Islam, Kristian, Katholik, Hindu, Buddha 
an seterusnya. Dengan itu, menjadi jelas bahawa sumber legitimasi PAN tidak bersumber secara eksklusif daripada Islam, namun daripada kesatuan agama-agama yang pelbagai.

Adapun berkait nasionalisme, tidak dapat dinafikan bahawa PAN adalah parti nasionalis, terbuka dan inklusif. PAN merupakan parti yang meletakkan landasan politiknya pada prinsip nasionalisme. Sebagai sebuah parti politik yang berhaluan nasionalis keagamaan (religious), PAN menunjukkan penghormatan yang amat tinggi terhadap nilai kebangsaan dalam kancah politik di Indonesia. Bagi PAN, kebangsaan merupakan tali pemersatu negara Kesatuan Republik Indonesia yang terdiri daripada beragam nilai, suku, budaya dan agama. ${ }^{44}$ Sebagai parti nasionalis, PAN menyokong dan memperjuangkan bentuk negara Kesatuan Republik Indonesia yang utuh, merdeka dan berdaulat. PAN merupakan parti politik nasionalis yang mendasarkan setiap gerak dan langkah politiknya pada nilai-nilai moral agama sebagai landasan perjuangannya. PAN memahami bahawa nilai-nilai kebangsaan dan agama amatlah berkait erat antara satu dan lainnya. Kebangsaan dan spiritualitas merupakan dua perkara yang saling berkelindan antara satu dan lainnya. Kedua-duanya mestilah wujud dan sentiasa dibina dalam diri setiap warga negara Indonesia. 45

Menurut pengamatan penulis, dengan dijadikannya nasionalisme sebagai landasan politik parti, maka Islam mulai tergusur sedikit demi sedikit dari dalam tubuh PAN. Memang, Islam tidak akan tergusur sepenuhnya, namun keberpihakan parti politik tersebut untuk meletakkan nilai-nilai kebangsaan di atas nilai-nilai keislaman, menyebabkan Islam semakin terpinggir dan hanya dianggap sebagai sumber nilai alternatif sahaja. Islam tidak lagi diletakkan sebagai sumber nilai politik tertinggi namun diletakkan lebih rendah hanya sekedar sebagai sumber nilai pelengkap, penyedia inspirasi atau faktor komplementer sahaja. Dengan demikian, Islam diletakkan sejajar dengan agama-agama lain dan dianggap sebagai salah satu unsur sekunder sahaja. Ketika Islam, dan bahkan agama-agama lainnya sekalipun, hanya menjadi faktor pelengkap (supplementary) sahaja, maka legitimasi tidak lagi didapatkan daripada Islam. Ianya didapatkan daripada sesuatu landasan politik yang dibentuk berdasar atas kesepakatan-kesepakatan antar agama yang kemudian disesuaikan dengan tuntutan-tuntutan nilai kebangsaan. Jadi nilai-nilai sejagat yang disepakati oleh seluruh agama semacam keadilan, perdamaian, toleransi dan sebagainya, semestinya difahami dan diletakkan secara bersesuaian dengan konteks Indonesia sebagai sebuah bangsa yang pelbagai.

Dengan mewawarkan kesamaan nilai sejagat sedemikian rupa, PAN bersikap berhati-hati untuk memberikan pemaknaan secara lebih terperinci terhadap nilai-nilai tersebut. Oleh itu, parti politik ini memandang tidak perlu untuk memperbincangkan upaya pemaknaan seumpama ini. PAN memahami bahawa, pemaknaan tersebut justeru akan menimbulkan perbezaan dan bahkan menyebabkan perpecahan dalam kalangan masyarakat. Ini merupakan antara isu sektarianisme yang tidak perlu diperdebatkan lebih jauh dalam kehidupan masyarakat yang pelbagai. Menurut PAN, hendaknya sikap eksklusif atau sektarian, perlu diredam selama-lamanya. Justeru PAN meyakini bahawa dalam kehidupan berbangsa dan bernegara, sikap terbuka dan inklusif mesti ditanamkan dalam diri seluruh bangsa Indonesia.

Dari analisis ini, dapat difahami mengapa PAN lebih memilih Pancasila berbanding Islam sebagai ideologi parti. Bagi PAN, ideologisasi Islam dalam parti politik merupakan bentuk formalisme agama dan bukti nyata sektarianisme yang semestinya dihapuskan dari bumi Indonesia. Islam mestilah disajikan dalam bentuknya yang inklusif sehingga dapat diterima oleh semua pihak tanpa adanya kekhawatiran akan berlakunya tindakan-tindakan diskriminasi terhadap mereka. Perjuangan politik Islam secara substantif merupakan keharusan dan oleh itu perlu diutamakan berbanding perjuangan secara formalistik. Dalam hal ini, seorang tokoh PAN, Achmad Rubaie menyatakan bahawa: 
PAN tidak memperjuangkan formalisasi Islam namun substansi Islam. Dengan pilihan tersebut, PAN ingin melihat bagaimana orang-orang bukan Islam juga mengamalkan nilai-nilai Islam sehingga Islam dapat menjadi magnet bagi mereka karena merasa nyaman. ${ }^{46}$

Dengan melepaskan diri daripada ikatan legitimasi Islam, PAN telah beralih menjadi parti politik nasionalis-sekular yang mendapatkan legitimasi politiknya daripada nilai-nilai kebangsaan. Komitmen untuk memperjuangkan nilai-nilai politik Islam telah berubah menjadi komitmen untuk memperjuangkan nilai-nilai kebangsaan. Paradigma dan sikap politik parti politik tersebut tidak lagi didasarkan dengan mengacu pada nilai atau cita-cita politik Islam, namun diselenggarakan secara bersesuaian dengan nilai-nilai nasionalisme semata atau secara sederhana dapat pula disimpulkan bahawa perjuangan politik PAN lebih ditentukan oleh identiti nasionalisnya berbanding identiti keislamannya.

Kesimpulan seumpama ini dapat dianalisis melalui kenyataan yang disampaikan oleh beberapa tokoh PAN. Ketika ditanya mengenai sikap parti berkait kes Syiah dan Ahmadiah, para politisi PAN menyatakan bahawa negara hendaknya bersikap hati-hati dengan tetap menjaga perdamaian diantara kelompok-kelompok yang bertikai serta menahan diri untuk tidak terlalu dalam bagi mencampuri urusan keyakinan masyarakatnya. Lebih lanjut, Sekjen PAN dan Wakil Ketua Dewan Perwakilan Rakyat (DPR) Republik Indonesia (RI) Taufik Kurniawan menyatakan bahawa:

PAN tidak dalam posisi melarang atau membiarkan Ahmadiyah sebagai keyakinan. Harus ada kajian yang lebih mendalam, karena ini bukan soal persepsi perorangan, tapi keputusan institusi pemerintah. ${ }^{47}$

Ketika dimintai keterangan berkait perkara ini, Ahmad Rubaie menyatakan:

Kalau konteksnya ajaran, maka kita mesti mendalami agama tersebut. Disini negara tidak bisa campur tangan. Namun ketika dimasukkan dalam konteks negara, iaitu bahawa teryata kewujudan kelompok Ahmadiyah tersebut dapat menimbulkan ketegangan di masyarakat, maka negara bisa masuk. Karena tugas negara adalah melindungi segenap warga negara. Jadi negara tidak dapat masuk ke wilayah ajarannya. Negara hanyalah fasilitator saja. Ajaran adalah hak dan urusan masing-masing penganut agama. ${ }^{48}$

Kenyataan lebih tegas disampaikan oleh M. Najib. Menurut beliau:

Negara tidak boleh abai terhadap masalah yang dihadapi oleh anak bangsa, siapapun dia dan apapaun masalah tersebut. Menyelesaikan masalah2 minoritas agama, tidak boleh diperkecualikan sepertimana negara mengurusi permasalahan2 serupa di tempat dan kasus lain. Penyelesaikan tidak boleh dibeda-bedakan. Terhadap syiah, tidak boleh diselesaikan dengan kebencian, karena pendekatan semacam itu sudah gagal di banyak negara. Tuntutan mayoritas, ini mesti dihabisi. Ini tidak boleh ditolerir. Yang terpenting adalah kesadaran ummat dan pendidkan mereka. Orang bodoh itu susah bijaksana. Jadi kita perlu memberikan pengertian terhadap tokohtokoh agama, karena tidak semua tokoh tersebut mengerti agama. ${ }^{49}$

Ketika diminta pendapat tentang desakan Majelis Ulama Indonesia terhadap pemerintah untuk melarang atau membubarkan Ahmadiyah, M. Najib berucap: 
Ya pendekatan-pendekatan itu harus dihindari. Negara tidak boleh abai terhadap masalah-masalah yang dihadapi oleh anak bangsa, siapapun dia dan apapun masalah tersebut...Tuntutan mayoritas, ini (bahawa Ahmadiyah) mesti dihabisi, tidak boleh ditolerir. Yang terpenting adalah kesadaran dan pendidikan ummat. Orang bodoh itu kan susah bijaksana. Jadi kita perlu memberikan pengertian terhadap tokoh-tokoh agama, karena tidak semua tokoh tersebut mengerti agama. ${ }^{50}$

Menurut pengamatan penulis, kenyataan seumpama ini menunjukkan bahawa PAN bersikap neutral ketika menyikapi isu Ahmadiyah. Parti politik ini bersikap berhati-hati untuk menunjukkan sikap ketidakberpihakan mereka terhadap mana-mana kelompok yang tengah bertikai. Dengan bersikap neutral dan tidak menunjukkan keberpihakan terhadap salah satu kelompok, PAN meyakini bahawa negara tidak seharusnya mengurusi perkaraperkara privat, semacam keyakinan atau kepercayaan, masyarakatnya. Negara hendaknya berhenti di depan pintu masjid atau pintu gereja dan tidak perlu masuk ke dalamnya kerana ianya adalah ruang yang sangat peribadi dan negara tiada kuasa untuk ikut campur di dalamnya. Oleh itu, negara hanya berperanan ketika para penganut keyakinan-keyakinan tersebut saling berbenturan dan kemudian menimbulkan pertelingkahan atau permasalahan di masyarakat. Dengan begitu, hendaknya negara berperanan sebagai media, wadah atau penyedia kemudahan bagi penganut keyakinan-keyakinan yang pelbagai tersebut.

Demikianlah tuntutan nilai-nilai kebangsaan yang perlu diamalkan oleh PAN. Untuk menjadi parti nasionalis, PAN mesti menunjukkan sikap toleran, inklusif dan terbuka. Nasionalisme juga menuntut PAN untuk tidak berpihak secara eksklusif terhadap Islam kerana yang demikian akan menimbulkan kecemburuan dalam kalangan penganut agama dan kepercayaan lainnya. Oleh itu, PAN memilih untuk berperanan sebagai mediator atau penengah sahaja di atas isu Ahmadiyah tersebut berbanding bersikap tegas untuk menyatakan bahawa Ahmadiyah adalah bukan Islam dan oleh itu mesti keluar daripada agama Islam (menjadi agama baharu tersendiri). ${ }^{51}$ Berdasarkan pengamatan di atas, penulis melihat bahawa ketika negara (parti) bersikap neutral di atas setiap permasalahan dan tidak mengamalkan sesuatu langkah politik tertentu, sepertimana seharusnya diperintahkan oleh Islam, maka sekularisme pada basis legitimasi sememangnya telah wujud dan berlaku.

\section{Sekularisme Pada Identiti Kelompok}

Antara perkara paling asasi dalam sekularisme budaya politik adalah terbentuknya sesuatu identiti kebangsaan sekular. Dalam sistem masyarakat moden, masalah pertautan identiti dan kesetiaan terhadap bangsa bagi individu-individu tertentu, boleh jadi sama kritikalnya dalam banyak hal dengan masalah identiti keagamaan. Kemunculan nasionalisme di Barat sememangnya melibatkan pergantian nilai-nilai dan identiti agama menjadi nilai-nilai dan identiti kebangsaan sebagai orientasi utama bagi kehidupan sosial dan politik masyarakatnya. Dengan begitu, maka nasionalisme moden menggantikan agama sebagai faktor utama dalam pelbagai bentuk hubungan sosial. 52

Berkait PAN, sekularisme pada identiti kelompok seumpama ini wujud ke dalam beberapa sikap dan kebijakan politik tertentu. Antara kebijakan politik dimaksud adalah keterbukaan parti untuk menerima keanggotaan daripada pelbagai golongan utamanya golongan bukan Islam. Bahkan, sepertimana telahpun penulis perbincangkan sebelum ini, parti juga membenarkan golongan bukan Islam untuk menjadi pengurus, dan bahkan ketua umum parti dan juga anggota dewan atau parlemen. Apabila diperbandingkan antara jumlah Muslim dan bukan Islam dalam jajaran pengurus parti dan anggota dewan, bilangan Muslim adalah lebih ramai. Meskipun demikian, tidak mustahil lambat laun perbandingan seumpama ini akan berubah dan jumlah bukan Islam dalam jajaran pengurus parti dan 
anggota dewan melebihi jumlah Muslim. Dengan menjadi parti terbuka seumpama ini, karakter PAN sebagai parti Islam mulai hilang dan dalam kalangan masyarakat mula dikenali sebagai parti nasionalis.

Antara kebijakan politik lainnya adalah keengganan PAN untuk disebut sebagai parti Islam. Kebijakan ini masih berkait rapat dengan pilihan parti politik tersebut untuk menjadi parti terbuka. Berikut antara kenyataan yang disampaikan oleh beberapa tokoh PAN berkait keengganan mereka untuk disebut sebagai parti Islam. Ketika menghadiri perayaan Christmas pada tarikh 22 Disember 2013 di Manado, Hatta Rajasa menyatakan bahawa, "PAN adalah bukan partai eklusif tetapi inklusif (terbuka, Red). Di dalamnya seluruh masyarakat Indonesia bisa bergabung. Kami tidak membeda-bedakan siapa pun".53

Demikian pula kenyataan yang disampaikan oleh Bara Hasibuan Ketua Dewan Pengurus Pusat PAN Bidang Hubungan Luar Negeri:

Kami sadar di Sulut sebagian orang masih melihat PAN sebagai partai agama. Tapi saya tegaskan itu tidak betul sama sekali. ${ }^{54}$

Media salah kalau terus memasukkan PAN dalam kategori partai Islam. Sejak awal didirikan PAN adalah partai inklusif dan terbuka. Sebagai bukti bahwa PAN bukan partai Islam adalah satu-satunya posisi Ketua Komisi di DPR yang dimiliki PAN dipegang oleh Laurens Bahang Dapa yang beragama Kristen. Para calon legislatif (Caleg) PAN pada Pemilu 2014 nanti juga banyak yang beragama Kristen, Hindu maupun Budha. 55

Sementara itu, Ketua Badan Pemenangan Pemilu PAN Viva Yoga Mauladi, mengatakan bahawa partinya adalah parti nasionalis dan bukan parti Islam. ${ }^{56}$

Dengan nada serupa, ketika menghadiri perayaan Christmas di Jayapura pada tarikh 13 Januari 2013, Sekretaris Jenderal Dewan Pimpinan Pusat (DPP) PAN, Taufik Kurniawan juga menyuarakan bahawa, "kami ingin memberikan refleksi bahwa PAN itu parti inklusif dan plural yang dimiliki berbagai macam agama, etnis, dan sosial. PAN didirikan untuk seluruh lapisan masyarakat sesuai semangat pendiri PAN". .57

Demikianlah antara beberapa kenyataan yang disampaikan oleh beberapa tokoh PAN berkait keengganan mereka untuk menisbatkan Islam ke atas parti politik tersebut. PAN jelas tidak mahu disebut sebagai parti Islam namun bersetuju apabila disebut sebagai parti nasionalis. Realiti seumpama ini, menunjukkan bahawa identiti keislaman dalam PAN sememangnya telah tergusur dan diganti dengan sesuatu identiti politik baru yang dilekatkan secara rapat pada nilai-nilai kebangsaan. Memang terdapat beberapa kepentingan strategik di sebalik kebijakan politik seumpama ini. Antaranya adalah kepentingan untuk memperkenalkan citra Islam sebagai agama yang toleran, lebih terbuka dan inklusif serta kepentingan pragmatik untuk mendapatkan sokongan atau suara dalam setiap pilihan raya.

Selanjutnya, sekularisme pada identiti kelompok juga dapat dianalisis melalui pengamatan yang teliti terhadap keengganan PAN untuk berkoalisi dengan parti politik nasionalis-Islam serta keterbukaannya untuk berkoalisi dengan parti politik nasionalissekular. Manakala parti politik nasionalis-Islam merujuk kepada antaranya Partai Keadilan Sejahtera, Partai Bintang Reformasi dan sebagainya, parti nasionalis-sekular merangkumi antaranya Golongan Karya, Partai Demokrasi Indonesia-Perjuangan, Partai Demokrat, Hanura dan sebagainya. ${ }^{58}$

Koalisi politik yang pernah dibangun antara PAN dan parti-parti nasionalis-sekular tersebut adalah dalam beberapa pilihan raya Kepala Daerah (Pilkada) di beberapa wilayah di Indonesia. Antaranya adalah koalisi PAN dengan Golkar, Partai Demokrasi Indonesia Perjuangan (PDI-P), Partai Demokrat, Partai Damai Sejahtera (PDS), Partai Persatuan 
Pembangunan (PPP), Partai Patriot Pancasila (PP Pancasila) dan Partai Bintang Reformasi (PBR) untuk mengusung Abdillah dan Ramli sebagai calon walikota Medan melawan pasangan Maulana Pohan dan Sigit Pramono Asri untuk periode 2005-2010. Dalam Pilkada Kabupaten Tanjung Jabung Timur, Jambi, PAN mengusung pasangan Abdullah Hich dan M. Juber dan bekerjasama dengan sejumlah parti seperti Golkar, Partai Bulan Bintang, Demokrat, Partai Persatuan Demokrasi Kebangsaan, Partai Bintang Reformasi, Partai Nasional Indonesia Marhaenisme. Dalam Pilkada Kabupaten Cirebon, bersama beberapa parti lain seperti Partai Hati Nurani Rakyat, Demokrat, Gerindra, Golkar, Partai Damai Sejahtera, Partai Nasional Demokrat, Partai Nasional Benteng Kerakyatan Indonesia, Partai Keadilan Sejahtera (PKS), PPP dan lain-lain, PAN mendukung pencalonan Sri Heviyana Supardi dan Rakhmat sebagai bupati dan calon bupati Cirebon untuk periode 2013-2018.59

PAN juga berkoalisi dengan PDIP untuk mengusung pasangan Sigit Sumarhen Yanto dan Freddy Wijaya dalam Pilkada sebagai calon walikota dan wakil walikota Pekalongan untuk periode 2005-2010.60 Berkait pilihan raya Presiden dan Wakil Presiden 2014 yang lepas, PAN tidak bergabung dengan koalisi antara PDIP dan Partai Kebangkitan Bangsa (PKB) untuk mendukung pencalonan pasangan Joko Widodo dan Jusuf Kalla. Ini kerana PAN, bersama-sama Gerindra, Golkar, PKS, Demokrat dan PPP mengusung pasangan Prabowo dan Hatta Rajasa dalam pilihan raya tersebut. Meskipun demikian, beberapa akhbar harian memberitakan bahawa beberapa hari sebelum dilakukan pendaftaran pasangan calon Presiden dan Wakil Presiden di pejabat Suruhan Jaya Pilihan Raya Indonesia (KPU), PAN membuka wacana kemungkinan untuk berkoalisi dengan PDIP. Kenyataan seumpama ini, dibenarkan oleh Hatta Rajasa. Ketua Umum PAN ini menyatakan bahawa partinya membuka peluang untuk bekerjasama dengan PDIP pada Pemilu Presiden dan Wakil Presiden (Pilpres) 2014 kerana, “Hubungan antara PAN dan PDI Perjuangan selama ini cukup baik, komunikasi terus terjalin, sehingga kemungkinan untuk koalisi sangat terbuka" ${ }^{61}$

Wasekjen PAN, Teguh Juwarno juga tidak menafikan jika partinya mengadakan kerjasama dengan PDIP:

Sudah menjadi pembahasan informal di internal PAN. Ada yang pro dan kontra, namun yang mendukung semakin kuat. Yang pasti nyaris tidak ada kendala yang prinsipil terkait kedekatan kedua partai selama ini. Baik sesama pimpinan partai maupun di parlemen maupun. ${ }^{62}$

Keyakinan serupa juga ditunjukkan oleh Ketua DPP PAN, Bara Hasibuan:

Kami optimis koalisi ini terjadi. Kami dan PDIP punya visi misi yang sama ke depan. Kita juga sama-sama parpol terbuka dan partai nasionalis. PAN sedang giat mencari rekan koalisi yang berideologi sama. Dan salah satu yang terutama adalah PDIP. Kami merasa cocok. Hubungan itu memang sudah sejak lama terjalin. 63

Meskipun akhirnya pakatan antara PAN dan PDI-P tersebut gagal terbentuk, namun hasrat politik sepertimana ternampak dalam beberapa kenyataan politisi PAN di atas menunjukkan bahawa PAN tetap terbuka untuk menjalin koalisi dengan parti pimpinan Megawati tersebut.

Demikianlah antara langkah politik PAN yang menunjukkan sekularisme pada identiti kelompok. Sekali lagi perlu ditegaskan bahawa, sekularisme pada tahap ini wujud paling tidak dalam tiga langkah politik di atas iaitu keterbukaan parti, terhapusnya identiti keislaman yang mewujud dalam keengganan parti untuk disebut sebagai parti Islam, dan 
kesediaan parti untuk membina pakatan politik dengan beberapa parti politik berhaluan nasionalis-sekular.

\section{Polity-Dominance Secularization}

Sekularisme pada tahap ini sememangnya cukup berbeza dengan tiga tahap sekularisme sebelumnya. Manakala ketiga tahap sekularisme yang pertama ditimbulkan oleh prosesproses sekularisasi politik yang berlaku hampir di seluruh dunia, sehingga cukup mudah untuk dianalisa, sekularisme pada tahap ke empat ini hanya berlaku di beberapa negara tertentu sahaja. Dengan begitu, dapat dikatakan ianya bukanlah sebuah fenomena sejagat dan tidak berlaku secara merata di seluruh negara di dunia. ${ }^{64}$ Smith mensifatkan bahawa manakala polity-separation secularization memutuskan ikatan antara agama dan sesuatu pemerintahan (polity), polity-dominance secularization berupaya menciptakan ikatan-ikatan institusional baru untuk dapat mengontrol agama. Apabila polity-expansion secularization menunjukkan pertumbuhan pemerintahan tersebut di atas merosotnya pengaruh agama dalam mengatur masyarakat, maka polity-dominance bergerak melampaui keadaan seumpama itu untuk menafikan otonomi agama.

Demikian juga berkait sekularisme pada tahap ketiga. Ketika polity-transvaluation menimbulkan pensekularan budaya politik yang berlaku secara bertahap, polity-dominance melibatkan serangan pemerintah secara terang-terangan atau terbuka terhadap basis agama dari budaya secara umum dan pemaksaan ideologi sekular terhadap budaya politik masyarakatnya. ${ }^{65}$ Melalui pemaknaan seumpama ini, penulis meyakini bahawa ketiga bentuk sekularisme politik yang pertama iaitu polity-separation, polity-expansion dan politytransvaluation sememangnya wujud dalam PAN. Ini cukup berbeza dengan polity-dominace secularization. Penulis melihat bahawa sekularisme pada tahap ini tidak atau belum berlaku dalam tubuh parti politik tersebut. Tidak ditemukan bukti-bukti yang cukup kuat untuk menyatakan bahawa telah berlaku pemaksaan nilai-nilai atau ideologi sekular dalam PAN.

Menurut pengamatan penulis, karakter seumpama ini menjadi keunikan tersendiri bagi PAN. Sebagai parti politik yang dizahirkan daripada rahim organisasi massa terbesar kedua di Indonesia, iaitu Muhammadiyah, dan sokongan yang relatif meluas daripada ummat Islam, menjadikan PAN tidak dapat melepaskan diri daripada disebut sebagai parti Islam. Tentu sahaja, sokongan yang cukup signifikan seumpama ini menjadikan PAN perlu menampung seluruh aspirasi politik mereka. Jadi di situ terdapat unsur-unsur keislaman apabila PAN mesti memperjuangkan cita-cita politik ummat Islam. Di samping itu, selain semangat keislaman, penghormatan yang tinggi terhadap nasionalisme menjadikan PAN perlu berfikir panjang untuk memperjuangkan kepentingan politik seluruh bangsa Indonesia tanpa mengira perbezaan latar belakang agama, sosial, politik, pendidikan dan jenis kelamin mereka. Inilah pilihan politik yang ingin diperjuangkan oleh PAN iaitu memperjuangkan aspirasi politik ummat Islam dan aspirasi ummat-ummat lainnya dalam satu ayunan langkah kepartian yang moden, demokratis dan terbuka.

Dengan berusaha menampung cita-cita keislaman dan kebangsaan dalam satu hembusan nafas seumpama ini, maka terkadang PAN mesti berdepan dengan pilihanpilihan politik yang serba rumit. PAN perlu meyakinkan sesetengah golongan Islam untuk tidak memaksakan kehendak mereka dengan, misalnya, memberlakukan Piagam Jakarta, ${ }^{66}$ atau menjadikan Islam sebagai ideologi parti, atau penubuhan negara Islam sebagai matlamat politik parti dan sebagainya. Pada saat yang sama, PAN juga berusaha meyakinkan golongan nasionalis-sekular dan bukan Islam bahawa perjuangan politik mestilah dikaitkan secara relatif dengan agama (Islam). Dalam hal ini, PAN telah menggariskan Anggaran Dasar dan Rumah Tangga dan platform parti yang penuh dengan istilah-istilah keagamaan yang bersumber khasnya daripada Islam. Biarpun istilah-istilah 
tersebut difahami secara terbuka, namun yang pasti ianya menunjukkan keterkaitan parti dengan nilai-nilai keagamaan (Islam).

Dalam usaha memperjuangkan cita-cita politik seumpama ini, sehingga kepada tahap tertentu, PAN berjaya memadukan cita-cita politik Islam dan kebangsaan. Namun pada peringkat tertentu, agaknya cita-cita politik kebangsaan mendapatkan keutamaan berbanding cita-cita politik keislaman. Pada ketika itulah sekularisme politik berlaku. Realiti seumpama inilah yang penulis cuba wawarkan dalam perbincangan di atas. Namun meskipun cita-cita kebangsaan lebih diutamakan daripada cita-cita politik keislaman, bukan bererti bahawa pengutamaan tersebut berlaku secara terang-terangan atau dipaksakan secara massive oleh para petinggi parti. Sekularisme politik tersebut sememangnya disedari dan diterima secara sukarela oleh PAN dan, tambahan pula, ianya berlaku secara berperingkat. ${ }^{67}$ Dengan demikian, penulis berkeyakinan bahawa polity-dominance secularization tidak atau belum terjadi di tubuh PAN.

\section{Kesimpulan}

Sebagai kesimpulan, sekularisme politik dalam tubuh PAN memiliki kaitan yang amat erat dengan wacana hubungan Islam dan negara. Untuk itu, perlu dilakukan kajian yang menyeluruh berkait wacana tersebut sama ada dalam konteks sejarah politik di Indonesia mahupun di dalam tubuh PAN sendiri. Memang terdapat dinamika dan perubahan dalam paradigma parti politik Islam di Indonesia ketika penulis menganalisa isu tersebut di atas. Paradigma politik lama yang cenderung simbolistik-formalistik kini mula ditinggalkan ummat Islam dan beralih untuk memilih paradigma politik baru yang bernuansa substansialistik. Dengan menjadi parti Islam substansialistik, PAN menerima demokrasi dan nasionalisme, berbanding Islam, sebagai landasan politiknya. Maka disinilah sekularisme politik tersebut muncul.

Secara ringkas, sekularisme politik tersebut dapat dilihat daripada beberapa kebijakan parti untuk menjadi parti nasionalis, demokratik dan terbuka. Secara lebih spesifik sekularisme politik tersebut mewujud dalam ketidakberpihakan parti secara eksklusif terhadap Islam, keengganan untuk disebut sebagai parti Islam, struktur keanggotaan dan kepengurusan yang pelbagai, membuka kemungkinan kepemimpinan politik daripada golongan bukan Islam, mendukung kepemimpinan politik daripada golongan perempuan, sumber legitimasi politik yang disandarkan bukan pada Islam namun pada nilai-nilai kebangsaan, membangun pakatan politik dengan beberapa parti nasionalis-sekular demi mengejar kepentingan pragmatis dan sebagainya. Meskipun berhasil menampilkan gaya politik Islam yang terbuka, demokratis dan lebih toleran, namun sekularisme politik di atas menyebabkan parti mula kehilangan jatidiri ideologisnya dan terperangkap dalam permainan politik Indonesia yang pragmatis.

\section{Nota}

$1 \quad$ Merujuk kepada mereka yang memilih gerakan transformasi sosial dengan cara menawarkan Islam yang ramah dan tidak terlalu ideologis seperti yang telah berlaku di Indonesia sebelum tahun 1970-an. Lihat Bahtiar Effendy, (Re)politisasi Islam: Pernahkah Islam Berhenti Berpolitik? Jakarta: Penerbit Mizan, 2000, hlm. 191.

2 Budhy Munawar Rachman, Argumentasi Islam Untuk Sekularisme; Islam Progresif dan Perkembangan Diskursusnya, Jakarta: PT Gramedia Widiasarana Indonesia, 2010, hlm. 101-107.

3 Bahtiar Effendy, Islam and the State in Indonesia, Singapore: Institute of Southeast Asian Studies, 2003, hlm. 23.

4 Ketika hangatnya perbincangan mengenai hubungan Islam dan negara, muncul suatu paradigma politik baru yang berupaya menengahkan dua cabang pemikiran politik lama di Indonesia. 
Mengikut klasifikasi santri-abangan seperti yang diwar-warkan oleh Geertz, gerakan politik umat Islam di Indonesia menjelma ke dalam dua kelompok pemikiran yang sangat ekstrim iaitu kelompok nasionalis-Islam dan kelompok nasionalis-sekular. Dikotomi santri-abangan seumpama ini menyebabkan munculnya dua kelompok Islam, masing-masing dengan sentimen budaya yang berbeza yang kemudian berkembang menjadi aliran-aliran politik yang saling bersaing bagi memperebutkan kuasa dan pengaruh di pentas politik kebangsaan di Indonesia. Kedua-dua golongan Islam dan kebangsaan ini tidak bersepakat mengenai hubungan yang tepat antara agama (Islam) dan negara. Secara amnya, golongan Islam (nasionalis-Islam) mengajukan Islam sebagai dasar negara, sebaliknya golongan kebangsaan (nasionalis-sekular) menginginkan negara yang bersikap neutral terhadap agama. Untuk keterangan lanjut, sila lihat Clifford Geertz, Abangan, Santri dan Priyayi dalam Masyarakat Jawa, Jakarta: Pustaka Jaya, 1981, hlm. 14.

5 Lili Romli, Islam Yes, Partai Islam Yes: Sejarah Perkembangan Partai-Partai Islam di Indonesia, Jakarta: Pustaka Pelajar, 2006, hlm. 122. Perkara ini juga dijelaskan oleh Sri Utaria. Menurut beliau, dengan meyakini paradigma politik substantif, PAN meyakini bahwa Islam tidak menentukan peraturan-peraturan bernegara dan sistem pemerintahan. Meskipun memiliki asas sokongan daripada Muhammadiyah, PAN tidak menggunakan Islam sebagai asas politiknya. Lihat Sri Utaria, 'Tipologi Politik Partai Islam di Indonesia: Kontestan Pemilu 2004', Latihan Ilmiah B.A., Fakultas Syariah, Institut Agama Islam Negeri (IAIN) Yogyakarta, 2008, hlm. 107, 112 dan 117.

6 Teori sekularisasi politik yang dirumuskan oleh Smith merupakan hasil kajian sosial, politik dan keagamaan yang dilakukannya bagi mengetahui proses-proses modenisasi yang berlaku di beberapa negara di Asia Tenggara, Asia Selatan, Timur Tengah, Afrika Utara dan Amerika Latin. Kajian beliau juga mengkaji pengaruh atau respon yang ditunjukkan oleh agama-agama tertentu yang wujud dalam negara-negara tersebut terhadap proses modenisasi politik yang tengah berlaku. Antara hasil dapatan yang beliau kemukakan; bahawa Hinduisme, Buddhisme, Islam dan Kristian Katholik memiliki sikap dan dan pengaruh yang amat berlainan antara satu dan lainnya berkait proses modenisasi tersebut. Untuk keterangan lanjut, lihat Donald Eugene Smith, Religion and Political Development, Boston, USA: Little, Brown and Company, 1970, hlm. 85-123.

7 Kenyataan seumpama ini wujud dalam beberapa perdebatan yang berlaku di antara tokoh-tokoh nasional berkaitan hubungan Islam dan negara. Perdebatan-perdebatan yang dimaksudkan adalah antara Soekarno dan M. Natsir pada akhir tahun 1930-an, antara kelompok nasionalis Islam dengan nasionalis sekular dalam sidang-sidang Badan Penyelidik Usaha-Usaha Persiapan Kemerdekaan Indonesia (BPUPKI) dan Panitia Persiapan Kemerdekaan Indonesia (PPKI) pada tahun 1945, antara Nurcholish Madjid dengan H.M. Rasyidi dan Endang Saifuddin Anshari pada tahun 1970, dan antara kelompok nasionalis sekular yang diwakili oleh Denny J.A. dengan nasionalis Islam yang diwakili oleh Ahmad Sumargono pada tahun 1997-1999. Lihat misalnya Ahmad Syafi'i Ma'arif, Islam dan Masalah Kenegaraan: Studi Tentang Percaturan dalam Konstituante, Jakarta: LP3ES, 1996; Mohammad Natsir, Islam Sebagai Dasar Negara, Bandung: Pimpinan Fraksi Masyumi dalam Konstituante, 1957; Endang Saifuddin Anshari, 'The Jakarta Charter of June 1945; a History of the Gentlement's Agreement Between the Islamic and the Secular Nationalist in Modern Indonesia', Disertasi M.A., Institute of Islamic Studies, McGill University, Kanada, 1976; B.J. Boland, Pergumulan Islam di Indonesia (1945-1972), Jakarta: PT. Grafiti Pers, 1985; Muhammad Kamal Hassan, Muslim Intellectual Responses to "New Order" Modernization in Indonesia, Kuala Lumpur: Dewan Bahasa dan Pustaka, 1982; dan Denny J.A. et al., Negara Sekuler: Sebuah Polemik, Jakarta: Putra Berdikari Bangsa, 2000.

8 Anggaran Dasar dan Anggaran Rumah Tangga PAN, Hasil Kongres III PAN di Batam, Januari 2010, hlm. vii.

9 Ibid.

10 Ibid.

11 Pentafsiran Ketuhanan Yang Maha Esa seumpama ini, dilihat sebagai pentafsiran yang paling benar sama ada mengikut kaedah sejarah, tekstual mahupun kontekstual. Lihat perbincangan lanjut mengenai kenyataan ini dalam Adian Husaini, Pancasila Bukan Untuk Menindas Hak Konstitusionil Umat Islam; Kesalahpahaman dan Penyalahpahaman terhadap Pancasila 1945-2009, Jakarta: Gema Insani, 2009, hlm. 131-178. 

sekularisasi yang diwacanakan oleh Nurcholish Madjid sekitar tahun 1970-an. Antara kenyataan yang paling terkenal pada ketika itu adalah, "Islam Yes; Partai Islam No" seperti yang diwarwarkan oleh Nurcholish Madjid dan "Islam bukanlah ideologi politik" oleh Abdurrahman Wahid. Melalui kenyataan-kenyataan ini, kelompok progresif yang diwakili oleh kedua-dua tokoh di atas telah mewar-warkan wacana yang mengharuskan Islam untuk melepaskan diri daripada tuntutan politiknya dan lebih memusatkan diri terhadap pengembangan aspek spiritual sahaja. Menurut Yudi Latif, realiti seumpama ini merupakan puncak polity-separation secularization. Lihat Yudi Latif, Dialektika Islam; Tafsir Sosiologis atas Sekularisasi dan Islamisasi di Indonesia, Jakarta: Jalasutra, 2007, hlm. 19.

16 Penulis melihat bahawa secara amnya sekularisasi hukum, pendidikan, struktur sosial dan ekonomi dapat berlaku melalui kaitannya dengan peranan dan tanggungjawab negara. Namun pada pandangan parti politik, sekularisasi dapat dianalisa hanya pada kategori struktur sosial sahaja. Ini kerana wilayah hukum, pendidikan dan ekonomi berada di bawah kuasa dan pentadbiran negara.

17 Donald Eugene Smith, Religion and Political Development, hlm. 109-110.

18 Nuim Hidayat, "Partai Islam dan Inklusifitas", laman web, http://majalah.hidayatullah.com/lain-lain/opini-lain-lain/partai-islam-dan\%E2\%80\%9Cracun\%E2\%80\%9D-inklusifitas.html, diakses pada 25 Julai 2014.

19 Ketiga-tiganya adalah antara para pendiri PAN.

20 Yosef dan Jeremy merupakan calon anggota legislatif 2014-2019 dari Daerah Pilihan DKI III.

21 Untuk maklumat lanjut tentang calon anggota legislatif DPR RI, lihat laman web http://www.kpu.go.id/, diakses pada 25 Julai 2014.

22 Lihat "Siapkan Caleg Berkualitas, PAN Juga Ajukan Calon Non-Muslim", laman web http://news.liputan6.com/read/568193/siapkan-caleg-berkualitas-pan-juga-ajukan-calon-nonmuslim, diakses pada 3 Januari 2014.

23 Lihat "PAN akomodasi Caleg Non-Muslim", laman web http://microsite.metrotvnews.com/metronews/read/2013/04/22/1/148586/PAN-AkomodasiCaleg-Nonmuslim, diakses pada 12 Oktober 2013. Kenyataan serupa juga disampaikan oleh Ketua DPP PAN, Bima Arya dan Sekretaris Jenderal PAN, Taufik Kurniawan. Menurut keduadua tokoh PAN tersebut, PAN adalah parti inklusif dan plural yang dimiliki oleh seluruh warga Indonesia tanpa membeza-bezakan latar belakang agama, etnik dan sosial. Lihat "PAN jadi partai liberal, gelar perayaan natal tingkat nasional di papua", laman web http://m.voaislam.com/news/indonesiana/2013/01/14/22740/pan-jadi-partai-iberal,gelar-perayaan-nataltingkat-nasional-di-papua, diakses pada 1 April 2013.

24 Untuk perbahasan lanjut mengenai perkara ini, sila rujuk Muhammad Hamidullah, al-Wathaiq alSiyasiyyah Li 'Ahdi al-Nabawiyyah wa al-Khilafah, Cairo: Matba'ah Lajnah al-Ta'lif wa al-Tarjamah, 1956, hlm. 112; Said Ramadan, Islamic Law; Its Scope and Equity, Kuala Lumpur: Muslim Youth Movement of Malaysia, 1987, hlm. 126. 
Untuk maklumat lanjut, sila rujuk Muhammad Abdul Rauf, The Concept of Islamic State: With Particular Reference to Treatment of Non-Muslim Citizens, Kuala Lumpur: Islamic Affairs Division, Prime Minister Department, 1988, hlm. 51.

Dalam Islam, seorang pemuda Muslim dibolehkan untuk mengahwini wanita bukan Islam sama ada wanita tersebut adalah penganut Kristian atau Yahudi. Namun untuk seorang Muslimah, hak seumpama ini tidak berlaku. Seorang Muslimah tidak dibenarkan untuk berkahwin dengan seorang pemuda bukan Islam, bahkan wanita Muslimah hanya dibenarkan untuk berkahwin dengan seorang pemuda Muslim sahaja. Untuk perbahasan lebih lanjut mengenai perkara ini, sila rujuk Muhammad Hamidullah, Introduction to Islam, Paris: Centre Culturel Islamique, 1969.

Berkaitan jawatan-jawatan tertentu di bawah autoriti kekuasaan seperti jawatan menteri atau timbalan menteri, para fuqaha' membolehkan golongan bukan Islam untuk mentadbir atau menguruskannya. Mereka diberikan kebebasan untuk saling berlumba dengan golongan Muslim untuk mengisi jawatan-jawatan dimaksud. Lihat ibid., hlm. 148-151.

Al-Quran, surah al-Nisa, ayat 59. Perkataan "kalangan kamu" difahami untuk merujuk secara eksklusif kepada umat Islam sahaja.

Berkaitan pendapat Sayyid Qutb, sila lihat Sayyid Qutb, Fi Zilal al-Quran, Beirut: Dar al-Shuruq, 1979, hlm. 907. Berkaitan Abu al-A'la al-Mawdudi, sila rujuk Abu al-A'la al-Mawdudi, The Islamic Law and Constitution, Lahore: Islamic Publication Ltd, 1960, hlm. 295.

Rasulullah SAW dan Abu Bakar al-Siddiq misalnya pernah menggunakan khidmat Abdullah Ibn al-Arqat untuk menghantar atau memandu mereka dalam perjalanan (Hijrah) dari Makkah menuju Madinah. Lihat Muhammad Abdul Rauf, The Concept of Islamic State, hlm. 82. Rasulullah SAW juga pernah meminta nasihat daripada Abdullah Ibn Ubay Ibn Abi Salul sebelum Peperangan Uhud. Lihat Hasan Ibrahim Hasan, Tarikh al-Islam, Cairo: Maktabah al-Nahdhah, 1964, hlm. 111.

Abu al-A'la al-Mawdudi, The Islamic Law, hlm. 295-296.

Ibid., hlm. 284.

Laman web http://www.indomedia.com/bernas/042001/19/UTAMA/20uta3.htm, diakses pada 29 Ogos 2013. Kenyataan serupa juga disampaikan oleh Ketua Dewan Pimpinan Pusat PAN pada ketika itu, A.M. Fatwa. Dalam Musyawarah Kerja Wilayah I DPD PAN Banten, beliau mengungkapkan sokongan tersebut sambil meminta Megawati untuk bersikap akomodatif terhadap parti politik yang menyokonngnya. Lihat AM. Fatwa, "PAN Mendukung Megawati Menjadi Presiden," laman web http://news.liputan6.com/read/16577/am-fatwa-panmendukung-megawati-menjadi-presiden, diakses pada 13 September 2013.

Mohammad Hashim Kamali, Freedom, Equality and Justice in Islam, Kuala Lumpur: Ilmiah Publisher, 2002, hlm. 66-69.

Wanita dibolehkan menjadi pemimpin sesebuah negara apabila mereka dapat memenuhi beberapa syarat tertentu, antaranya kemampuan (capability) dan dapat diterima (acceptability) oleh orang ramai. Lihat Naqiyah Mukhtar, "Kepala Negara Perempuan Muslimah; Analisis Wacana TerhadapTafsir Quraish Shihab”, Jurnal Komunika Sekolah Tinggi Agama Islam Negeri Purwokerto, Vol. 5 No. 2, 2011, hlm. 159-184; Munfaridah, 'Wanita Sebagai Kepala Negara; Studi Pemikiran Ulama dalam Fiqh Siyasah,' Latihan Ilmiah B.A., Fakultas Syariah, Insitut Agama Islam Negeri Yogyakarta, 2001, hlm. 103.

Donald Eugene Smith, Religion and Political Development, hlm. 113-114

Ibid.

Ibid., hlm. 115.

Platform dan Anggaran Dasar Anggaran Rumah Tangga Partai Amanat Nasional, Hasil Kongres III PAN di Batam, 8-10 Januari 2010, hlm. vii-viii.

Lihat Platform PAN dalam Muhammad Najib (ed.), Sejarah Berdirinya PAN, Jakarta: DPP PAN, 2007, hlm. 141.

Jimly Asshiddiqie dan Linus Suryadi Agustinus, Islam dan Kedaulatan Rakyat, Jakarta: Gema Insani, 1995, hlm. 26-27; M. Imdadun Rahmat, Ideologi Politik PKS: Dari Masjid Kampus ke Gedung Parlemen, Jogjakarta: LKiS, 2008, hlm. 219-20; Taufiq Muhammad Asy-Syawi, Syura Bukan Demokrasi, Jakarta: Gema Insani, 1997, hlm. 583. 
John L. Esposito dan John O. Voll, Demokrasi di Negara-Negara Muslim, Bandung: Mizan, 1999, $\mathrm{hlm}$. 31. Pendapat seumpama ini dipegang oleh beberapa tokoh modernis dan neomodernis seperti Mohammad Natsir dan M. Amien Rais. Lihat Yudi Latief, Dialektika Islam: Tafsir Sosiologis atas Sekularisasi dan Islamisasi di Indonesia, Yogyakarta: Jalasutra, 2007, hlm. 38.

Setiap manusia merupakan khalifah Allah SWT di muka bumi ini. Mereka juga dibebani tugasan untuk menyampaikan dan melaksanakan perintah Penciptanya serta mencegah daripada kemungkaran. Manusia hanyalah pelaksana kedaulatan Allah SWT dan harus tunduk kepada ketentuan yang telah diberikan-Nya sebagai pemilik kedaulatan. Mereka harus tunduk kepada hukum yang lebih tinggi iaitu hukum syariah. Oleh itu, dapat difahami bahawa khalifah Allah di muka bumi sememangnya ditujukan kepada kaum Muslimin sahaja. Lihat Munawir Sadzali, Islam dan Tata Negara; Ajaran, Sejarah dan Pemikiran, Jakarta: University Indonesia Press, 1993, hlm. 172-173; Mustafa H. Daud, Tamadun Islam; Edisi Maktab Perguruan, Kuala Lumpur: Utusan Publication, 2004, hlm. 98; Mana Sikana, Berdiri di Akar Diri: Kritikan Sastera Melayu Pascamoden, Kuala Lumpur: Institut Terjemahan dan Buku Malaysia, 2013, hlm. 14. hlm. 54 Ibid., hlm. 11. Laman web http://nasional.news.viva.co.id/news/read/203964-ppp-dukung-ahmadiyah-jadiagama, diakses pada 15 Mei 2014.

48 Temu bual dengan Achmad Rubaie (Anggota DPR RI, fraksi PAN, 2009-2014), 23 September 2013.

49 Temu bual dengan M. Najib (Anggota DPR RI, fraksi PAN, 2009-2014), 24 September 2013.

50 Ibid.

51 Berkaitan sikap Islam terhadap kewujudan Ahmadiyah, sila lihat laman web http:// www.hidayatullah.com/artikel/tsaqafah/read/2011/02/17/1488/solusi-problemahmadiyah.html\#.VAfyfVe0r5M dan laman web http://insistnet.com/menyikapi-nabi-palsudan-ahmadiyah/, diakses pada 25 Ogos 2014.

$52 \quad$ Donald Eugene Smith, Religion and Political Development, hlm. 117.

53 Laman web http://www.beritasatu.com/nasional/157034-hatta-pan-bukan-partai-berbasisagama-tapi-nasionalis-terbuka.html, diakses pada 19 Mei 2014. Hatta mengemukakan PAN bukan parti agama tetapi sebagai parti nasionalis terbuka. Jika selama ini PAN dikenali sebagai parti agama yang berasaskan Islam, maka kenyataan itu tidak benar.

54 Laman web http://www.beritasatu.com/nasional/157034-hatta-pan-bukan-partai-berbasisagama-tapi-nasionalis-terbuka.html, diakses pada 26 Mei 2014.

55 Laman web http://www.beritasatu.com/nasional/152160-bara-hasibuan-pan-bukan-partaiislam.html, diakses pada 23 Ogos 2014.

56 Laman web http://politik.news.viva.co.id/news/read/458008-diajak-bentuk-poros-tengah--pan-kami-bukan-partai-islam, diakses pada 23 Ogos 2014.

57 Laman web http://www.republika.co.id/berita/nasional/politik/13/01/13/mgkb49-taufikpan-partai-terbuka, diakses pada 23 Ogos 2014.

58 Berkaitan tipologi parti politik seperti ini, lihat Lili Romli, Islam Yes Partai Islam Yes, hlm. 123.

59 Untuk perbincangan lanjut tentang Pilkada, sila lihat Nyarwi Ahmad, Siasat Partai Politik dan Strategi Pencalonan Kandidat Dalam Pilkada, Jakarta: Lingkaran Survei Indonesia, Edisi 3-Julai 2007.

60 Ibid.

61 Laman web http://www.solopos.com/2014/03/23/pemilu-2014-pan-akui-buka-pintu-koalisidengan-pdip-498151?mobile_switch=mobile, diakses pada 2 Ogos 2014.

62 Laman web http://www.merdeka.com/politik/gara-gara-jokowi-pan-ngebet-koalisi-denganpdip.html, diakses pada 3 September 2014.

63 Laman web http://www.tribunnews.com/pemilu-2014/2014/03/30/pan-optimistis-koalisidengan-pdip-di-pilpres-2014, diakses pada 13 Ogos 2014.

64 Menurut Smith, Polity-Dominance Secularism ini berlaku hanya di beberapa negara seperti Perancis, Mexico, Rusia, Turki dan China. Lihat Donald Eugene Smith, Religion and Political Development, hlm. 118. 
Ibid., hlm. 119.

Pada 22 Jun 1945, Badan Penyelidik Usaha-Usaha Kemerdekaan Indonesia (BPUPKI) yang terdiri daripada 9 orang anggota, iaitu; Soekarno, Mohammad Hatta, A.A Maramis, Abikoesno Tjokrosoejoso, Abdul Kahar Muzakkir, Haji Agus Salim, Achmad Soebardjo, Abdul Wahid Hasjim dan Muhammad Yamin, bersetuju bahawa sebuah gentlemen agreement atau kesepakatan kehormatan yang dimaksudkan sebagai Pembukaan Undang-Undang Dasar negara Indonesia. Untuk keterangan lanjut tentang hubungan negara dan Islam di Indonesia, lihat B.J. Boland, Pergumulan Islam di Indonesia, (1945-1972), Jakarta: PT Grafiti Pers, 1985, hlm. 29-30; Indah Putri Indriany, 'Islam dan Negara di Indonesia; Pemikiran Politik Abdurrahman Wahid', Disertasi M.A., Fakultas Ilmu Sosial dan Ilmu Politik, Univeristas Indonesia, 2002, hlm. 3.

67 Istilah "Sekularisme Ringan/Sederhana" (Mild Secularism) seperti yang disebut oleh Abdurrahman Wahid mungkin sesuai untuk menggambarkan ciri khas sekularisme dalam PAN. Parti ini tidak bersetuju sepenuhnya dengan idea penyatuan agama dan negara atau pemisahaan kedua-duanya secara radikal. Jadi, di satu sisi PAN lebih memilih untuk tidak menjadikan Islam sebagai ideologi parti. Di sisi lain, PAN tidak pula sepakat dengan prinsip sekularisme yang melazimi pemisahan agama dan negara secara total. Istilah "Mild Secularism" yang disebut oleh Abdurrahman Wahid sememangnya merupakan jalan tengah yang perlu diambil untuk menghindari dua pilihan ekstrim tersebut. Lihat Abdurrahman Wahid, I'ndonesia's Mild Secularism', SAIS Review, Vol. 21, 2001, hlm. 25-28. 